\title{
Effect of oyster mariculture on submerged aquatic vegetation: an experimental test in a Pacific Northwest estuary
}

\author{
Richard A. Everett*, Gregory M. Ruiz**, James T. Carlton*** \\ University of Oregon, Oregon Institute of Marine Biology, Charleston, Oregon 97420, USA
}

\begin{abstract}
The effects of commercial culture of oysters, Crassostrea gigas, on submerged aquatic vegetation (SAV), Zostera marina, were examined with replicated field experiments in the South Slough estuary, Oregon, USA. Both stake and rack methods of oyster culture resulted in significant decreases in the abundance of SAV compared to undisturbed reference areas. SAV cover in both stake and rack treatments was less than $25 \%$ of that in reference plots after $1 \mathrm{yr}$ of culture, and was absent from rack treatments after 17 mo of culture. Field experiments using marked plants revealed no difference in growth between plants in stake and reference plots. Comparisons of sediment surface topography demonstrated that oyster culture resulted in significantly greater sediment deposition in stake plots and greater erosion in rack plots. Silt-clay fractions and carbon content of sediments tended to increase with stake culture and decrease with rack culture, but only for carbon content at racks were the differences significant between culture and reference plots. Stake culture likely affected SAV via increased sedimentation and direct physical disturbance during placement and harvest, while increased erosion and perhaps shading resulted in the marked decrease in SAV coincident with rack culture. These results indicate the potential for significant loss of SAV from estuarine ecosystems where these methods of oyster culture and SAV coincide.
\end{abstract}

KEY WORDS: Eelgrass · Zostera marina - Oysters · Crassostrea gigas · Mariculture

\section{INTRODUCTION}

Submerged aquatic vegetation (SAV) is an important component of many estuarine and coastal marine communities. Beds of SAV often support higher abundances of animals than do comparable unvegetated bottoms (e.g. Petersen 1918, Kikuchi 1966, 1980, Orth 1977, Orth \& Heck 1980, Pollard 1984, Summerson \& Peterson 1984, Sogard \& Able 1991) and can be important nursery areas for commercially and ecologically valuable species (Thayer \& Phillips 1977, Zieman 1982 ,

Present addresses:

-U.S. Fish \& Wildlife Service, Chesapeake Bay Estuary Program, 177 Admiral Cochrane Drive, Annapolis, Maryland 21401, USA.E-mail: rich_everett@mail.fws.gov

- Smithsonian Environmental Research Center, PO Box 28 Edgewater, Maryland 21037, USA

-..Williams College Mystic Seaport, Maritime Studies Program, Mystic, Connecticut 06355, USA
Heck \& Thoman 1984, Thayer et al. 1984). Furthermore, SAV can influence community structure and function through a complex suite of physical, chemical and biological mechanisms (e.g. West \& Larkum 1979, Stoner 1980, Heck \& Thoman 1981, Fonseca et al. 1983, Ward et al. 1984, Eckman 1987, Wilson et al. 1987, Irlandi \& Peterson 1991).

Coastal regions are increasingly influenced by rising human population densities and associated activities (Olsen \& Burgess 1967, Odum et al. 1974, Neilson \& Cronin 1981), and anthropogenic impacts on SAV have often been severe (Thayer et al. 1975, Short et al. 1989, 1991). Boat traffic, pollution, dredging activities, and commercial fishing practices have all altered the abundance and distribution of SAV (e.g. Odum 1963, Peres \& Piccard 1975, Meinesz \& Laurent 1978, Correll \& Wu 1982, Zieman 1982, Cambridge \& McComb 1984, Borum 1985, Twilley et al. 1985, Shepherd et al. 1989, Larkum \& West 1990 , 
Pulich \& White 1991). Extensive areas of the coastal zone, especially estuarine and bay habitats, are now also used intensively for mariculture on most continents (Shaw 1969, Tenore et al. 1985, van der Veer 1989, Pillay 1992). Mariculture activities in estuaries often overlap spatially with the distribution of SAV (Taylor 1954, Thomas \& Duffy 1968, Ye et al. 1991, Rönnberg et al. 1992). While several studies have documented mariculture-induced changes to physical-chemical environments and fauna (Dahlback \& Gunnarsson 1981, LaPointe et al. 1981, Ottman \& Sornin 1985, Tenore et al. 1985, Brown et al. 1987, Ritz et al. 1989, Baudinet et al. 1990, Tsutsumi et al. 1991, Ye et al. 1991), the effects of mariculture on SAV have received comparatively little study.

The commercial oyster industry is an example, and is frequently the main component, of rapidly increasing coastal mariculture (Hunter \& Brown 1985). In North America, oysters have been grown commercially in estuaries, bays, and lagoons since the early 19th century, and the cultivation of oysters has increased tremendously during the 20 th century. The area of bay or estuarine habitat currently devoted to oyster mariculture in North America by far exceeds that devoted to producing any other species (Menzel 1991). Thus, understanding modifications to the local environment caused by cultivation of oysters provides a good model not only for mariculture practices in general, but also for the culture of species that frequently dominate mariculture worldwide.

In this study, we measured experimentally the effects of 2 methods used for commercial oyster culture on biotic and physical aspects of eelgrass Zostera marina beds in the South Slough estuary, Oregon, USA. Specifically, we compared changes in the cover, density, and growth of eelgrass and the physicalchemical characteristics of bottom sediments between plots with and without oyster culture.

\section{METHODS}

Study site. South Slough $\left(43^{\circ} 20^{\prime} 15^{\prime \prime} \mathrm{N}, 124^{\circ} 19^{\prime} 30^{\prime \prime} \mathrm{W}_{\mathrm{i}}\right.$ Fig. 1) is the southern arm of the larger Coos Bay estuarine system. The tidal flats of South Slough are lined at their lower edges by beds of the eelgrass Zostera marina, which extend subtidally. Tides in South Slough are semidiurnal, with a range of approximately $4 \mathrm{~m}$. Tidal velocities in the main channel, measured near the rack experiment site (below and Fig. 1), average about $0.5 \mathrm{~m} \mathrm{~s}^{-1}$, with maximum flows of approximately $0.9 \mathrm{~m} \mathrm{~s}^{-1}$ (unpubl. data from South Slough National Estuarine Research Reserve). More detailed descriptions of South Slough may be found in Pregnall \& Rudy (1985) and Posey (1988).

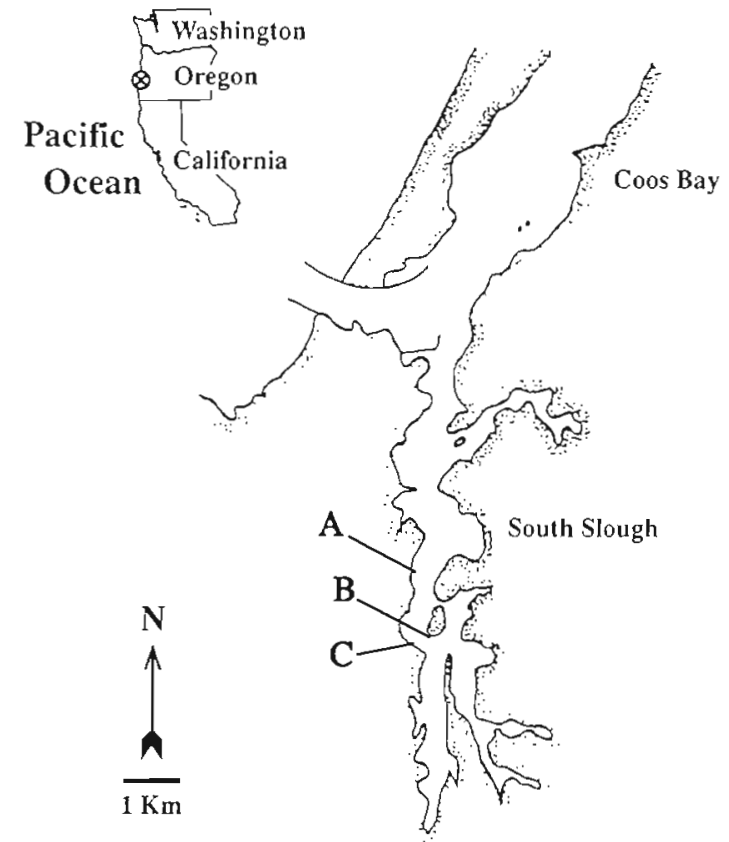

Fig. 1. Location of the Coos Bay estuarine system (upper left) on the Pacific coast of southern Oregon, USA, and locations of (A) rack, (B) 1988 stake and (C) 1989 stake experiment sites in South Slough

South Slough has supported commercial production of Pacific oysters Crassostrea gigas since the 1930s (L. Qualman, Qualman Oyster Co., pers. comm. 1988), and this fishery remains active today with annual production of approximately $270 \mathrm{~m}^{3}(\mathrm{H}$. W. Pendell, Oregon Dept of Agriculture, pers. comm. 1988). Bottom culture (i.e. oysters scattered on the sediment surface) and stake culture (i.e. oysters held approximately $30 \mathrm{~cm}$ above the bottom on wood or metal stakes) have been the major growing techniques used in this fishery. Stake culture began at South Slough in 1965 and is now the primary method used on approximately 40 ha of tidelands dedicated to commercial oyster culture (M. Graybill, South Slough National Estuarine Reserve, pers. comm. 1988). Recently, growers in South Slough have begun to experiment with rack culture, in which oysters are suspended on wires from fixed wooden racks. Stake culture is confined to the mid to low intertidal zone, and rack culture is located in the low intertidal to shallow subtidal zones. Both culture activities overlap extensively with the distribution of eelgrass in South Slough (authors' pers. obs.).

We established experimental plots of stake and rack culture, and accompanying reference plots without oyster culture, in the habitat where each culture method is typically found. Stake culture and reference plots were located along the low intertidal zone in an upper arm of South Slough (Fig. 1), where most com- 
mercial stake culture presently occurs within Coos Bay. Rack culture plots were placed in the extreme low intertidal zone just outside the Estuarine Reserve boundary, and adjacent to the only active commercial rack culture in South Slough (Fig, 1).

Specific sites for experiments were selected to provide replicate plots of approximately homogeneous eelgrass cover and surface topography (e.g. without channels or abrupt changes in slope). For each site, plots were arranged in a linear fashion along tidal isoclines. Oyster culture and reference plots were arrayed in pairs along a tidal isocline, and 1 plot of each pair was randomly designated for oyster culture. This paired design was chosen throughout to control for clinal changes (e.g. in current speed) that can exist across sites.

Stake culture. In October 1988, 4 experimental stake plots were established by transferring oyster stakes from adjacent commercial beds. The oyster stakes were steel rods, each holding 2 cultch shells, with multiple $(<10,1$ yr old $)$ oysters on each shell, approximately $30 \mathrm{~cm}$ above the sediment surface. The paired reference plots $(n=4)$ were established at the same time, and all plots were separated by $30 \mathrm{~m}$. Oyster stakes (196) in each experimental plot were placed approximately $0.5 \mathrm{~m}$ apart in arrays of $14 \times 14$, creating plots approximately $7 \times 7 \mathrm{~m}$; this stake density was chosen to reproduce commercial practices currently used in South Slough. The oysters in these 4 stake culture plots were commercially harvested in February 1989 using standard industry practices. During the harvest operation, men working on foot during a low tide period pulled up the stakes and loaded them on stainless steel sleds which were pushed over the sediment to the waterline for unloading at waiting boats.

A second set of stake and reference plots was established in November 1989, in a dense bed of eelgrass across from, but at the same tidal height as, the first set (Fig. 1). These stake plots were identical to the first set, except the cultch shells bore younger $(<2$ mo old) oysters. The stake (4) and reference (4) plots were laid out in a paired design along the tidal isocline (as stated above), with a minimum distance of $5 \mathrm{~m}$ between plots.

Rack culture. During the first $2 \mathrm{wk}$ of November 1988, 5 racks (sides $2.4 \times 3.0 \mathrm{~m}$, height $2.4 \mathrm{~m}$ ) were deployed in an eelgrass bed and immediately loaded with oysters (approx. 1 yr old). The racks were built with pressure treated (calcium chloride arsenic) lumber and lag bolts by fastening $5 \times 20 \mathrm{~cm}$ boards between corner posts $(10 \times 10 \mathrm{~cm})$ at the top and bottom. The racks were built on land and ferried out to the appropriate plot for deployment at high tide; all plots were separated by at least $30 \mathrm{~m}$. Once pushed into the water, the legs of each rack were worked into the sediment, and concrete blocks were placed around the top of racks for stability. The oysters were held on wires ( 5 cultch shells on each end, 40 wires per rack) suspended across 8 boards $(5 \times 10 \mathrm{~cm})$ which spanned the top of each rack.

Eelgrass cover and shoot density. For the rack and 1988 stake experiments, eelgrass cover in experimental and reference plots was quantified with a pointintercept quadrat method in November 1988, April 1989, and July 1989. A $25 \times 25 \mathrm{~cm}$ quadrat was divided into equal sized subareas with string, creating 25 points of intersection within the quadrat boundaries. The quadrat was dropped at 6 randomly determined locations on a transect through the middle of each plot (>1 $\mathrm{m}$ from plot edges), and the number of intersection points overlying eelgrass blades was counted.

Beginning in November 1989, eelgrass abundance in all experimental and reference plots was measured as shoot density within replicate $25 \times 25 \mathrm{~cm}$ quadrats. Shoot density was chosen because it provides greater resolution, compared to the point-intercept method, and is known to have important effects on the abundance and diversity of associated fauna (e.g. Heck \& Orth 1980, Stoner \& Lewis 1985, Sogard et al. 1987). The number and placement of samples was identical to point-intercept samples. In the first stake experiment, these censuses were conducted in November 1989, March 1990, and May 1990. Eelgrass shoot density in the second stake experiment was censused in May, July, August, and November 1990. In April 1990 shoot density in rack plots was recorded along the 2 transects used to quantify surface topography (below).

Eelgrass growth. The effect of stake culture on eelgrass growth was examined in 2 experiments conducted in the second set of stake and reference plots. For growth, net primary production of aboveground eelgrass was measured using a shoot-marking technique (e.g. Zieman 1974, Kentula \& McIntire 1986). In April 1990, 10 randomly selected shoots in each of 3 stake and 3 reference plots were tagged with uniquenumber markers (brass swivel hooks), which encircled the shoots and were attached to adjacent steel reference rods driven into the sediment. Holes were punched through the shoots at a known distance above the tops of the reference rods with a hypodermic needle, and shoot width (measured at the base of the first leaf) and length were recorded. After $14 \mathrm{~d}$, a second hole was punched through the leaves in an identical fashion. The length of leaf between the initial and final holes thus consisted of material added through growth over the experimental time interval. The marked shoots were collected, rinsed in fresh water to remove sediment and salts, and the portions of leaves between markings were cut out. Both the new growth material and the remainder were dried for $24 \mathrm{~h}$ at $80^{\circ} \mathrm{C}$, then weighed to the nearest $\mathrm{mg}$. 
In July 1990, a second growth experiment was conducted. Six Zostera marina shoots in each stake and reference plot were tagged and marked as described above. After $14 \mathrm{~d}$, the shoots were again marked, collected, and processed as above to determine the dry weight of recently added leaf material.

Algal biomass. No algae were present at the initiation of the experiments, but in August 1989 stake culture plots supported a lush growth of the green macroalga Ulva sp. To compare the amount of macroalgae in the experimental and reference treatments of both stake and rack experiments, we collected all algal material from 1 quadrat $(25 \times 25 \mathrm{~cm})$ that was randomly located within each plot. The algae were brought back to the lab and rinsed on a $0.5 \mathrm{~cm}$ screen to separate any sediment from the algae. Material retained on the sieve was immersed in a pan of clean seawater, and all algae were picked out by hand to remove all associated fauna. The cleaned algal samples were rinsed in fresh water, dried for $24 \mathrm{~h}$ at $80^{\circ} \mathrm{C}$, and weighed to the nearest $0.1 \mathrm{~g}$.

Sediment characteristics. Topography: The effects of stake and rack culture on local sediment surface topography were assessed by comparing the vertical profile of the experimental plots to reference points outside of the rack plots, and to profiles of stake culture reference plots. Profiles were measured along replicate transects through each experimental plot ( 3 transects for stake and reference plots, 2 transects for rack plots). The transects ran parallel to the tideline, and extended $2 \mathrm{~m}$ (stake and reference plots) or $3 \mathrm{~m}$ (rack plots) beyond the edges of the plots on each end. At each end of the transect, a line was attached to a metal pole $50 \mathrm{~cm}$ above the sediment surface. Vertical distances from the line to the sediment surface were measured at $0.25 \mathrm{~m}$ intervals along the transect and recorded to the nearest $\mathrm{cm}$. Rack surface profiles were measured on 15 August 1989, and stake plot surface profiles were measured on 29 November 1989. For the rack experiment, average height over the $3 \mathrm{~m}$ distance under the racks was compared with average height over $3 \mathrm{~m}$ at a distance from the rack $(1.5 \mathrm{~m}$ at each end of transects); for the stake experiment, average heights were calculated over the $6 \mathrm{~m}$ distance across each stake and reference plot.

Grain size: Changes in sediment grain size were compared between treatments (reference and experimental) during the first year of study. Core samples were taken from standard, pre-determined positions at the edge and center of each plot. For each position within plots, 4 core samples $(3 \mathrm{~cm}$ diameter $\times 1 \mathrm{~cm}$ deep) were pooled together. Although an understanding of local variation is lost in this fashion, we wanted to measure the average condition representative of the overall region (rather than undertake the effort involved in fine-scale mapping). Cores were taken within 1 wk after the creation of stake and rack experimental plots (October or November) and again $8 \mathrm{mo}$ later (July).

All sediment samples were individually labeled and kept frozen until analysis. For each sample, we measured the percentage dry weight of the sand and the combined silt and clay fractions $(<63 \mu \mathrm{m})$ of sediment (after Holme \& McIntyre 1971).

Carbon content: To assess the effects of oyster culture on the carbon content of sediments, a second set of samples was collected at the same times and locations, and in identical fashion, as those for grain size analysis. Samples, which had been stored frozen, were homogenized and treated with dilute hydrochloric acid to remove inorganic carbon (e.g. Grebmeier et al. 1988) and then analyzed for the percentage weight of carbon (Marine Science Institute Analytical Lab, University of California, Santa Barbara) with an automated CHN analyzer (Control Equipment Corp., Model 240XA).

Data analyses. Although sampling prior to a manipulation is preferred, the cumbersome nature of deployment did not permit sufficient control for exact knowledge of the final configuration/position of racks, and samples from stake plots were handled in a similar fashion for consistency throughout. Several aspects of our experimental design minimized the chance that we would measure natural patchiness rather than an effect of oyster culture. First, we located experimental arrays of oyster and reference plots in visually continuous beds of SAV. Second, we used a paired design, with treatment applied by random chance to individual plots within each pair.

Prior to analyses, all data were transformed $[、(n+1)$ for counts and arcsin $\overline{(n+1)}$ for proportions; Sokal \& Rohlf 1981) and tested for homoscedasticity using Cochran's test (Winer 1971). Specific tests used in each analysis are identified in 'Results'. In the event that transformation did not remove heteroscedasticity, nonparametric methods were used to test for treatment effects. For the purposes of this study, we considered $p$ values $<0.05$ to indicate statistical significance

\section{RESULTS}

\section{Eelgrass cover and shoot density}

Both stake and rack culture methods had negative effects on the abundance of eelgrass. In the first stake experiment, eelgrass cover was significantly lower in culture plots, compared to reference plots after just 2 wk of oyster culture in November 1988 (Fig 2A Table 1). Although the difference between percentage cover in stake and reference plots was not significant 


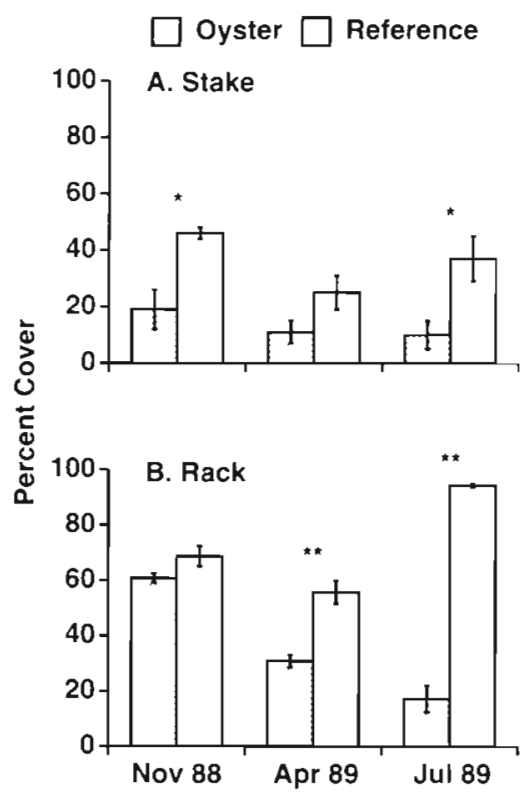

Fig. 2. Zostera marina. Percentage cover (mean \pm 1 SEM) by eelgrass in experimental (A) stake and (B) rack plots compared to reference plots, on 3 sample dates over the 9 mo period November 1988 to July 1989. Sample $=6$ quadrats $\left(0.06 \mathrm{~m}^{2}\right)$ per plot; asterisks indicate significant differences between experimental and reference plots: $p<0.05, \cdots p<0.005$

in April, the percentage cover by eelgrass in experimental stake plots was again significantly less than in reference plots by July, 9 mo after commencement of oyster culture.

Eelgrass shoot density was also significantly lower in experimental than in reference plots in the first stake experiment (Fig. 3A, Table 2). Following 1 yr of stake culture (November 1989), eelgrass shoot density in the culture plots was less than $25 \%$ of that found in reference plots, and this pattern persisted through May 1990, despite removal of stakes in February during commercial harvest. Significant differences in shoot density were detected among plots within treatments

Table 1 Zostera marina. Analysis of percentage eelgrass cover in experimental and reference plots in November 1989, and April and July 1990. Summary of F-ratios from 2-level nested ANOVAs with angularly transformed data. Degrees of freedom for analyses: stake experiment: 1,6 ; rack experiment: 1,8. ns: not significant

\begin{tabular}{|llrc|}
\hline Treatment & Date & F-ratio & $\mathrm{p}$ \\
\hline Stake & Nov & 7.24 & 0.05 \\
& Apr & 3.52 & ns \\
& Jul & 8.35 & 0.05 \\
Rack & Nov & 3.57 & ns \\
& Apr & 25.58 & 0.001 \\
& Jul & 154.25 & 0.001 \\
& & & \\
\hline
\end{tabular}

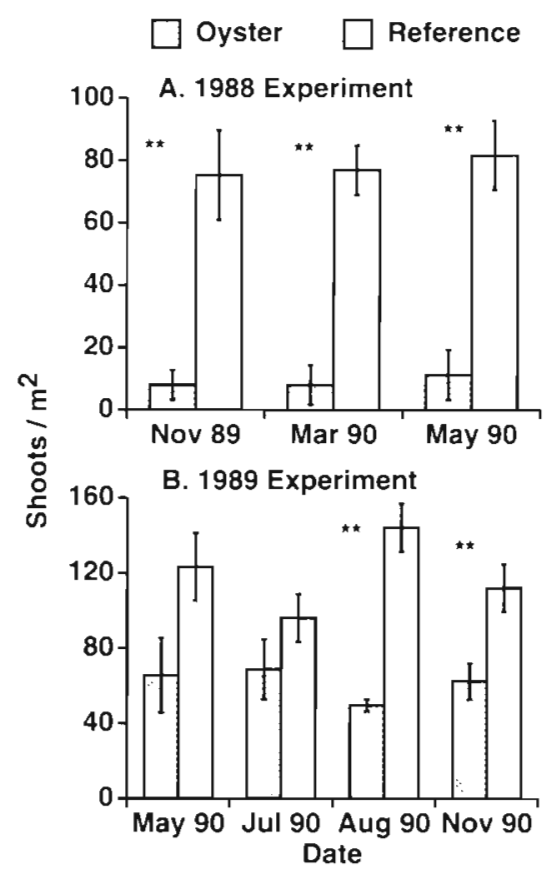

Fig. 3. Zostera marina. Density (mean \pm 1 SEM) of eelgrass shoots in experimental stake and reference plots (sample size and area as in Fig. 2). (A) 1988 experiment, plots established October 1988, harvested February 1990. (B) 1989 experiment, plots established November 1989. Asterisks indicate significant differences between experimental and reference treatments: $\cdots p<0.005$

in November 1989 (reflecting the natural patchiness of eelgrass density), but not on subsequent dates (Table 2). Recruitment of eelgrass seedlings was not observed in either stake or reference plots during the first stake experiment.

Oyster culture also had a negative effect on eelgrass shoot densities in the second stake experiment (Fig. 3B, Table 3). After 10 mo (August 1990), shoot densities in stake plots were significantly lower than in reference plots, and this difference persisted through the final

Table 2. Zostera marina. Analysis of eelgrass shoot density in first stake culture experiment. Summary of $F$-ratios produced in 2-level nested ANOVAs (square-root transformed data) for November 1989, March 1990, and May 1990. Main factor: treatment; nested factor plot. Degrees of freedom for all months: 1, 6 for oyster and 6,40 for plot. In all cases probability of error is less than tabled significance value ns: not significant

\begin{tabular}{|llrc|}
\hline Date & Source & F-ratio & $\mathrm{p}$ \\
\hline November & Oyster & 22.99 & 0.005 \\
& Plot (nested) & 2.91 & 0.025 \\
March & Oyster & 43.37 & 0.001 \\
& Plot (nested) & 0.48 & ns \\
May & Oyster & 18.47 & 0.005 \\
& Plot (nested) & 0.77 & ns \\
& & & \\
\hline
\end{tabular}


sampling in November, following 12 mo of stake culture. In addition, recruitment of eelgrass seedlings did occur in these study plots, and seedling abundance was significantly greater in reference plots than in stake plots in May (Table 4). This difference was no longer significant in July, and seedlings were not seen after July in either stake or reference plots.

Rack culture also had a significant effect on eelgrass cover and shoot density. Eelgrass cover at the initial census (November 1988) was similar for rack and reference treatments, but after 6 mo (April 1989), eelgrass cover in rack plots was approximately half of, and significantly different from, that found in reference plots (Fig. 2B, Table 1). The difference between rack and reference plots increased further by July 1989, after 9 mo of culture, reaching nearly $100 \%$ cover in reference plots compared to less than $20 \%$ cover under the racks (Fig. 2B, Table 1). By April 1990, after 18 mo of rack culture, eelgrass was essentially absent from the interior of the rack plots which were surrounded by a halo of low shoot density in an otherwise densely vegetated eelgrass meadow (Fig. 4).

\section{Eelgrass growth}

We found no significant effect of stake culture on the growth of eelgrass shoots in April or July. Analysis of covariance indicated no effect of size on the proportional growth of eelgrass shoots in either stake or reference plots in April and July (Table 5). Therefore, all sizes were pooled within plots for subsequent 2-level nested ANOVAs, with treatment as the main factor and plot as the nested second factor. Although no treatment effect was found (Table 6), both ANCOVA and ANOVA identified a significant within-treatment plot effect on eelgrass growth in April (Tables 5 \& 6).

Table 3. Zostera marina. Analysis of eelgrass shoot density in May, July, August, and November 1990 of the second stake culture experiment. Summary of 2 -level nested ANOVA (square-root transformed data) for each date (main factor. oyster treatment, stake vs reference; nested tactor: plot). Signuficance as in Table 2. ns: not significant.

\begin{tabular}{|llrlc|}
\hline Month & Source & F-ratio & $\mathrm{df}$ & $\mathrm{p}$ \\
\hline May & Oyster & 3.06 & 1,6 & $\mathrm{~ns}$ \\
& Plot & 19.15 & 6,72 & 0.001 \\
July & Oyster & 1.63 & 1,6 & $\mathrm{~ns}$ \\
& Plot & 2.50 & 6,40 & 0.05 \\
August & Oyster & 93.50 & 1,6 & 0.001 \\
& Plot & 0.20 & 6,16 & $\mathrm{~ns}$ \\
November & Oyster & 9.42 & 1,6 & 0.025 \\
& Plot & 1.95 & 6,32 & $\mathrm{~ns}$ \\
& & & & \\
\hline
\end{tabular}

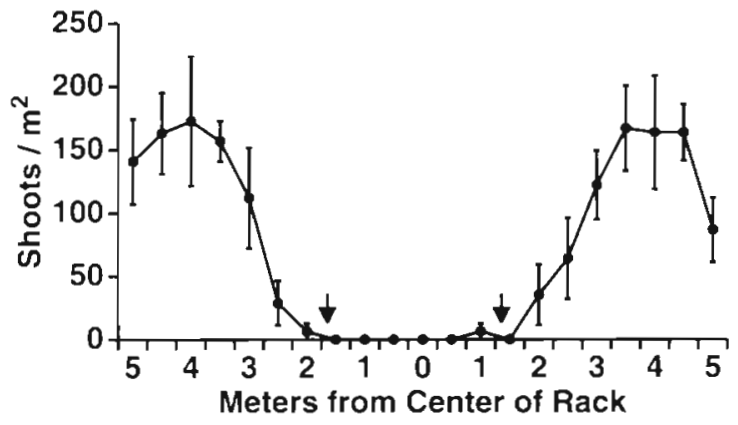

Fig. 4. Zostera marina. Density (grand mean \pm 1 SEM) of eelgrass shoots along transects through experimental rack plots in April 1990, following 18 mo of oyster culture. For each plot, data from 3 parallel transects were pooled to yield mean density at a particular distance from center of rack. Arrows indicate positions of edges of racks

\section{Algal biomass}

After 9 mo of oyster culture, mean algal biomass was significantly greater (Mann-Whitney $U=16$, $\mathrm{df}=4,4$, $\mathrm{p}<0.05)$ in stake plots $[136.2 \pm 54.9$ (SEM) g dry wt $\left.\mathrm{m}^{-2}\right]$ than in reference areas $\left(6.9 \pm 4.25 \mathrm{~g}\right.$ dry wt $\left.\mathrm{m}^{-2}\right)$. At the rack experiment the opposite was true, with mean algal biomass in rack plots $(38.1 \pm 3.2 \mathrm{~g}$ dry wt $\left.\mathrm{m}^{-2}\right)$ significantly less $(U=22, \mathrm{df}=5,5, \mathrm{p}<0.05)$ than in reference plots $\left(135.0 \pm 37.9 \mathrm{~g}\right.$ dry wt $\left.\mathrm{m}^{-2}\right)$. In all cases,

Fable 4. Zostera marina. Mean seedling density, no. $\mathrm{m}^{-2}$ (SEM), in plots with stake oyster culture and in. reference plots in May and July 1990. $F=$ Fisher's exact test $F$. ns: not significant

\begin{tabular}{|cccccc|}
\hline & Oyster & Reference & $F$ & $\mathrm{df}$ & $\mathrm{p}$ \\
\hline May & $1.6(0.6)$ & $11.2(3.2)$ & 9.46 & 1,6 & 0.025 \\
July & $4.8(1.6)$ & $12.8(6.4)$ & 2.27 & 1,6 & $\mathrm{~ns}$ \\
\hline
\end{tabular}

Table 5. Zostera marina. Analysis of percentage growth of marked eelgrass shoots in April and July 1990. Summary of ANCOVA within treatments (covariate: size = shoot width) .

Data arcsin square-root transformed. ns: not significant

\begin{tabular}{|lcccc|}
\hline & Source & F-ratio & df & $\mathrm{p}$ \\
\cline { 1 - 2 } April & & & & \\
Oyster & Plot & 7.27 & 2,26 & 0.003 \\
Reference & Size & 3.41 & 1,26 & $\mathrm{~ns}$ \\
& Plot & 2.48 & 2,26 & $\mathrm{~ns}$ \\
July & Size & 0.16 & 1,26 & $\mathrm{~ns}$ \\
Oyster & & & & \\
Reterence & Plot & 0.22 & 2,14 & $\mathrm{~ns}$ \\
& Size & 0.00 & 1,14 & $\mathrm{~ns}$ \\
& Plot & 2.97 & 2,14 & $\mathrm{~ns}$ \\
& Size & 2.17 & 1,14 & $\mathrm{~ns}$ \\
\hline
\end{tabular}


Table 6. Zostera marina. Mean percentage growth ( 1 SEM) of marked eelgrass shoots in April and July 1990; and summary of 2-level nested ANOVA between treatments, with plot as nested factor. Data arcsin square-root transformed. ns: not significant

\begin{tabular}{|c|c|c|c|c|}
\hline \multicolumn{2}{|c|}{ Percent growth } & Oyster & \multicolumn{2}{|c|}{ Reference } \\
\hline $\begin{array}{l}\text { April } \\
\text { July }\end{array}$ & & $\begin{array}{l}34 \pm 6 \\
30 \pm 3\end{array}$ & & $\begin{array}{l} \pm 2 \\
\pm 2\end{array}$ \\
\hline ANOVA & Source & F-ratio & $\mathrm{df}$ & Significance \\
\hline April & $\begin{array}{l}\text { Oyster } \\
\text { Plot }\end{array}$ & $\begin{array}{l}0.01 \\
5.51\end{array}$ & $\begin{array}{l}1,4 \\
4,54\end{array}$ & $\begin{array}{c}\text { ns } \\
0.005\end{array}$ \\
\hline July & $\begin{array}{l}\text { Oyster } \\
\text { Plot }\end{array}$ & $\begin{array}{l}0.69 \\
0.73\end{array}$ & $\begin{array}{l}1,4 \\
4,18\end{array}$ & $\begin{array}{l}\text { ns } \\
\text { ns }\end{array}$ \\
\hline
\end{tabular}

the green alga Ulva expansa was the predominant species present, with a mix of other brown and green algal species present in very small amounts. Although the average biomass of algae was almost identical in experimental stake plots and rack reference plots, there was a noticeable qualitative difference between the algal cover in the 2 treatments. Algae in the stake plots were present as large blades, often anchored in place by the weight of deposited sediment and attachment to or entanglement with oyster stakes. In contrast, algae in rack reference plots were predominantly present as smaller blades entangled in the leaves of the eelgrass, and did not appear to be partially buried by sediment.

\section{Sediment characteristics}

Topography

Heavy erosion around the racks resulted in a complex surface topography, exhibiting pronounced trenches with an average depth of $15 \mathrm{~cm}$ on sides of the racks that were normal to tidal flow (Fig. 5A). Overall, the sediment surface under racks was significantly lower in profile relative to that immediately adjacent (Mann-Whitney $U$-test, mean difference under racks $=-8.1 \mathrm{~cm}, \mathrm{SD}=6.2$; mean difference adjacent to racks $=1.7 \mathrm{~cm}, \mathrm{SD}=1.0, U=25, \mathrm{p}=0.009)$. Although height of the sediment surface in the middle of the racks appeared similar to that of the reference points at the ends of the transects, the sediment grain size in the interior of the racks was visibly coarser than outside, suggesting the occurrence of scour and sorting effects in the center as well as at the edges (but see results of grain size analysis below).
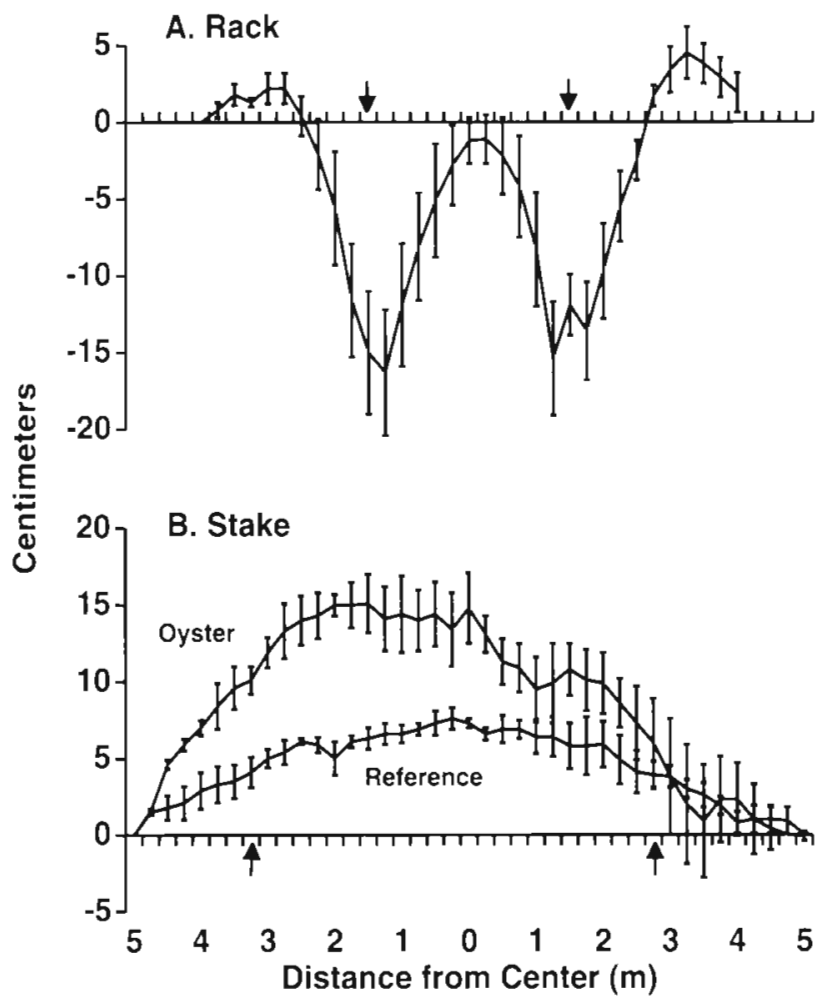

Fig. 5. Effects of (A) stake and (B) rack oyster culture on sediment surface topography following 9 and 12 mo of culture, respectively. Shown are average ( 1 SEM) vertical profiles $(\mathrm{cm})$ at $0.25 \mathrm{~m}$ intervals along replicate transects through each plot. Profiles are standardized to endpoints of each transect; arrows indicate edges of experimental plots

Stake culture also resulted in changes to surface topography, although via deposition rather than scour. Following 12 mo of oyster culture, the sediment surface profiles demonstrated a significant mounding of sediment in the interior of the stake plots compared to the reference areas (Fig. 5B; mean height within stake plots $=11.6 \mathrm{~cm}, \mathrm{SD}=3.5$; mean height within reference plots $=6.0 \mathrm{~cm}, \mathrm{SD}=1.3$; paired $t$-test: $t=3.08, \mathrm{p}<0.05$ ). The apparent slight increase in the height of the sediment surface in reference plots was due to an unavoidable sagging of the reference line, which was stretched across a distance of $10 \mathrm{~m}$.

\section{Grain size}

There were trends for increased silt and clay fractions in the stake plots (Fig. 6A), and decreased fractions in the rack plots (Fig. 6B), relative to reference plots. However, despite approximately 2 -fold differences in mean percentage by weight of silt and clay between reference plots and center samples from both types of oyster culture, the differences were not signif- 

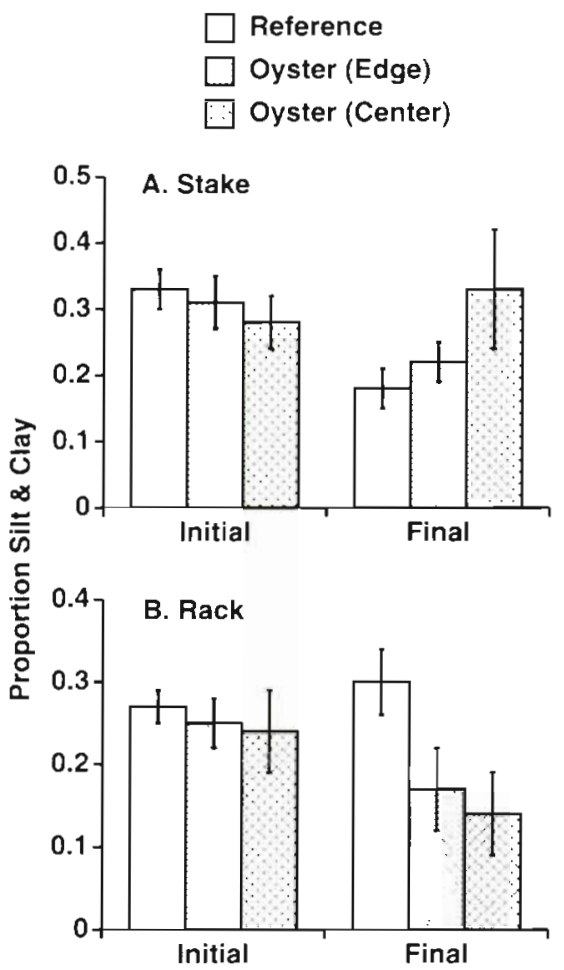

Fig. 6. Proportion silt and clay fraction (mean \pm 1 SEM) in sediment samples from experimental and reference plots in (A) stake and (B) rack experiments, after 9 and 8 mo respectively. Initial dates: stake experiment, October 1989; rack experiment, November 1989. Standard errors estimate variance among plots within a treatment and location: center and edge of experimental plots, and reference plots

icantly different when comparing edge and center samples separately to reference plots for rack or stake culture experiments (paired $t$-tests on transformed data; Table 7).

Table 7. Analysis of sediment carbon composition and grain size. Summary of pairwise comparisons (Student's t-test, data arcsin square-root transformed) between experimental and reference treatments. $C$ : center; $E$ : edge; ns: not significant; $n$ for stakes $=4$, for racks $=5$

\begin{tabular}{|lccccc|}
\hline & Position & \multicolumn{2}{c}{ Initial } & \multicolumn{2}{c|}{ Final } \\
& & $t$ & $p$ & $t$ & $\mathrm{p}$ \\
\hline Stakes & & & & & \\
Carbon & $\mathrm{C}$ & 0.488 & $\mathrm{~ns}$ & 0.656 & $\mathrm{~ns}$ \\
& $\mathrm{E}$ & 0.856 & $\mathrm{~ns}$ & 1.610 & $\mathrm{~ns}$ \\
Silt-clay & $\mathrm{C}$ & 0.333 & $\mathrm{~ns}$ & 1.325 & $\mathrm{~ns}$ \\
& $\mathrm{E}$ & 0.773 & $\mathrm{~ns}$ & 0.993 & $\mathrm{~ns}$ \\
Racks & & & & & \\
Carbon & $\mathrm{C}$ & 1.229 & $\mathrm{~ns}$ & 3.145 & 0.02 \\
& $\mathrm{E}$ & 2.148 & $\mathrm{~ns}$ & 2.433 & 0.05 \\
Silt-clay & $\mathrm{C}$ & 0.872 & $\mathrm{~ns}$ & 1.714 & $\mathrm{~ns}$ \\
& $\mathrm{E}$ & 1.852 & $\mathrm{~ns}$ & 2.068 & $\mathrm{~ns}$ \\
& & & & & \\
\hline
\end{tabular}

$\square$ Reference

Oyster (Edge)

Oyster (Center)

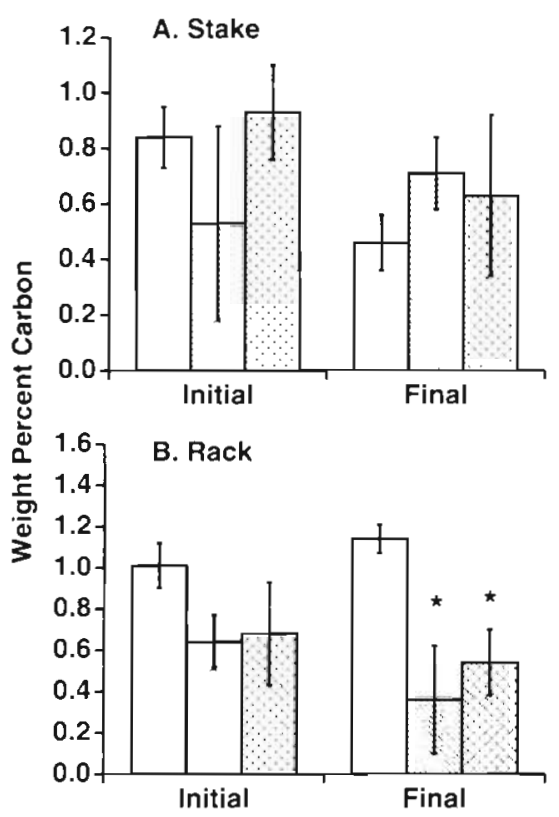

Fig. 7. Carbon content of sediments (mean \pm 1 SEM), expressed as weight percentage, in experimental and reference plots of (A) stake and (B) rack experiments. Sample date and size as in Fig. 6 and Table 7 ; asterisks indicate significant differences $(p<0.05)$ compared to reference plots

\section{Carbon content}

Similar to other measures of sediment characteristics, carbon analysis also suggested depositional and erosional environments for stake (Fig. 7A) and rack (Fig. 7B) cultures, respectively. For plots with stake culture, although the mean weights of carbon were higher than for reference plots, no significant differences were found comparing the edge or center of experimental to reference plots (Table 7). In contrast, there were significantly lower amounts of carbon in rack plots compared to reference plots that were not present in the initial samples (Fig. 7B, Table 7). The magnitude of these reductions was greatest at the edges, but formal comparisons of edge versus center were not made here (and elsewhere) because they are not independent samples (Sokal \& Rohlf 1981).

\section{DISCUSSION}

Stake and rack methods of oyster culture affected both macrophytic and sedimentologic characteristics of the intertidal benthic habitat of South Slough. The adverse effects of stake culture on eelgrass density 
were observed in 2 separate experiments, conducted in different years. Both culture methods apparently produced strong, although dissimilar, changes in local hydrological conditions, which had clear effects on sediment characteristics. In general, stakes resulted in local sediment deposition (Fig. 5B) while racks produced local erosion (Fig. 5A), most pronounced at the rack edges where trenches up to $25 \mathrm{~cm}$ deep were scoured in the sediment.

Increased deposition in stake plots resulted in a trend toward higher percentages of silt-clay sized particles (Fig. 6A) than in reference plots. Although not significantly different by treatment, the proportional weight of silt-clay in reference plots appeared to decrease between the initial and final samples of the stake experiment; no such change occurred in the centers of the stake plots. Similar comparison of results from the rack experiment suggests no change in the proportional weight of the silt-clay fraction in reference plots during the experiment, while in rack plots the proportional weight of silt-clay appeared to decrease (Fig. 6B). For both stake and rack culture, comparison of initial and final sediment carbon contents revealed similar patterns as seen for silt-clay fractions. The proportional weight of carbon seemed to decline in reference plots but not in the paired stake plots. Conversely, sediments in rack plots appeared to decrease in the proportional weight of carbon while weights in reference plots were unchanged, producing a significant difference between treatments (Fig. 7B).

Although we lack a priori data on the abundance of eelgrass in the plots, our experimental design provides several arguments against interpreting these results as representing natural variability in SAV distribution and abundance rather than an effect of oyster culture. First, because stake and rack experiments were purposely located in visually continuous SAV beds, and individual plots within pairs were randomly designated as reference or experimental, treatment effects were unlikely to correspond to a natural pattern of SAV abundance. Second, the patterns in SAV abundance and sediment surface topography which we attribute to oyster culture were highly localized around our experimental plots, as shown in Figs. $4 \& 5$. Third, and finally, we observed the same general pattern of lower SAV abundance within stake culture plots compared to reference plots (Figs. $2 \mathrm{~A} \& 3 \mathrm{~A}, \mathrm{~B}$ ) in 2 separate experiments, conducted at different sites within South Slough, in separate years.

The loss of eelgrass under and adjacent to racks (Figs. 2B \& 4) appeared to be a direct result of the high erosional environment created by the rack structures. However, other nonexclusive mechanisms may also have been operating. In particular, shading by the racks may have lowered light levels sufficiently to contribute to the decline in SAV. Our data on SAV and sediment topography do not indicate whether the scour effects were coincident with the loss of eelgrass, or followed as a consequence of the loss of sedimentstabilizing SAV. Placement of the racks undoubtedly damaged eelgrass and disturbed the sediment surface where the frame impacted the substratum. However, our initial observations of the rack plots immediately following establishment revealed no evidence of the extensive trenches seen later.

It is equally difficult to attribute the loss of eelgrass in areas of stake culture (Figs, 2A \& 3) to a particular mechanism. There were no differences between stake and reference plots in the growth of marked eelgrass shoots in either April or July 1990 (Table 6), thus stake culture does not appear to inhibit Zostera marina growth, at least at the level of the individual shoots. There were fewer $Z$. marina seedlings in stake plots in May 1990 (Table 4), so it may be that the replacement rate of senescent shoots is reduced by stake culture. We have, however, no demographic data for either the seedlings or older plants. The build-up of an algal mat in areas of stake culture may also reduce eelgrass abundance through shading and increased sediment deposition, as suggested in previous studies (Cowper 1978, Kentula \& McIntire 1986, Geyer et al. 1990).

Several nonexclusive mechanisms may have combined to stimulate algal cover in stake plots. First, the stakes and their attached oyster and epifaunal assemblages may have passively trapped drifting fragments of algae, which subsequently grew in situ. Second, the stakes may have provided a stable substratum for the attachment of sporelings and/or germlings in a habitat usually devoid of stable surfaces for settlement. Third, the slower currents in stake plots (indirectly indicated by sediment deposition) may have been too weak to wash away algae which had settled on small particulate substrata on the sediment surface.

There was a noticeable disturbance associated with the initial placement of the cultures in the stake experiments. The initial surveys, conducted immediately after the placement of the 2 culture treatments, demonstrated that eelgrass coverage was more similar between rack and reference sites than between stake and reference sites (Fig. 2). The racks were constructed on land, floated to the site at high tide, and then dropped into place. Except for the narrow peripheral band at which the lower edges of the racks met the sediment surface, this action had a negligible effect on the bottom. In contrast, stake plots were constructed, as is normally done by commercial growers, at low tide by teams of workers walking back and forth on the sediment surface as they placed the individual stakes. This intensive and highly localized activity 
had a visually dramatic effect on the bottom, which was churned and trodden into a muddy quagmire, and probably was a major cause of low eelgrass cover in stake plots at the time of our initial measurements.

Most studies of the effects of bivalve culture on benthic habitats, concerned primarily with raft and long-line mussel culture in deeper water, have found significant increases in sedimentation, due principally to biodeposition by the mussels and associated fouling organisms (Dahlback \& Gunnarsson 1981, Sornin et al. 1982, Tenore et al. 1982, Kaspar et al. 1985, Baudinet et al. 1990). At least 1 earlier study (Ottman \& Sornin 1985) examined the sedimentological consequences of intertidal culture methods very similar to the stake and rack methods employed in South Slough and elsewhere along the Pacific Coast of North America. Arrays of poles, or 'bouchots', resulted in local reduction of water velocity and increased deposition of sediment while large wood or metal tables holding bundles of mussels resulted in increased local erosion. These results are similar to those we observed for stake and rack culture, respectively, in South Slough.

Although previous studies have shown clear and drastic effects of mariculture on benthic fauna (e.g. Tenore et al. 1982, Mattsson \& Linden 1983, Kaspar et al. 1985), only a few studies (Waddell 1964, Ye et al. 1991) have considered the effects of mariculture on SAV. Our results from South Slough demonstrate experimentally that mariculture can have severe and negative impacts on submerged aquatic angiosperms in coastal habitats, and thus support quantitatively the earlier suggestions of Waddell (1964) and Ye et al. (1991). The effects of our replicated, small-scale experiments appeared to mimic the effects of large-scale commercial oyster culture in South Slough. We, as well as others (Pregnall et al. 1993, Graybill pers. comm.), have frequently observed geometrically regular areas devoid of shoots in the middle of extensive eelgrass beds, coinciding with current or previous areas of oyster culture. These observations, along with our replicated experimental results, indicate the existence of a consistent pattern of oyster culture impacts to eelgrass communities and suggest such effects may be widespread where oyster culture and eelgrass overlap in distribution.

Such decreases in SAV abundance as a result of oyster culture are of particular concern given the potential importance of eelgrass in estuarine primary productivity (McRoy \& McMillan 1977, Zieman \& Wetzal 1980), nutrient regeneration (McRoy et al. 1972, Twilley et al. 1986), sediment stabilization (Burrell \& Schubel 1977, Orth 1977, Christiansen et al. 1981, Fonseca \& Fisher 1986), and as habitat and trophic resource for a wide range of fauna (Kikuchi 1966, 1980, Thayer \& Phillips 1977, Jacobs et al. 1981, Peterson
1982, 1986, Orth et al. 1984, Heck et al. 1989, Edgar 1990, Lubbers et al. 1990, Wilson et al. 1990).

Regardless of the actual mechanisms involved, mariculture activities can produce a wide variety of cascading physical and biological effects in shallow estuarine waters. For example, deposition often increases mud (silt and clay) and organic loading in the environment (Dahlback \& Gunnarsson 1981, Baudinet et al. 1990, Ye et al. 1991), and can cause rapid changes in both animal and plant populations (Mattsson \& Linden 1983. Brown et al. 1987, Ritz et al. 1989, this study). Erosion for any reason can also result in altered sediment composition and organic content (this study) and can lead to extensive losses of plant and animal populations (e.g. Patriquin 1975, Zieman 1976). Mats of green algae, like those which developed in areas of stake culture in this study, can produce an extensive suite of alterations in sediment physical processes (Joint 1978, Frostick \& MCCave 1979, Zimmermann \& Montgomery 1984, Hull 1987, Lavery \& McComb 1991) and biotic community structure (Nicholls et al. 1981, Soulsby et al. 1982, Reise 1983, Hull 1987, Everett 1991, 1994).

As large areas of coastal habitat become devoted to intensive mariculture, it is increasingly critical to understand the range of modifications associated with these practices. Given the importance of SAV in the structure and function of coastal and estuarine communities, and the ongoing decline in the abundance of SAV in many estuaries around the world (e.g. Peres \& Picard 1975, Cambridge \& McComb 1984, Orth \& Moore 1984, Giesen et al. 1990, Larkum \& West 1990), a fuller understanding of the effects of mariculture is critical for development of sound management practices (Pillay 1992) driven by empirically based predictive models.

Acknowledgements. We particularly thank M. Graybill, Director, and S. Rumrill, Research Coordinator, South Slough National Estuarine Research Reserve for their valuable assistance. For help in the field and laboratory we thank K. Kiefer, S. Davidson, J. Hall, J. Geller, C. Hewitt, T Johnson, and E. McLaren. This research was supported by NOAA grants NA88A-D-CZ015 and NA89AA-D-CZ044 to J.T.C.

\section{LITERATURE CITED}

Baudinet D, Alliot E, Berland B, Grenz C, Plante-Cuny MR, Plante R, Salen-Picard C (1990) Incidence of mussel culture on biogeochemical fluxes at the sediment-water interface. Hydrobiologia 207:187-196

Borum J (1985) Development of epiphytic communities on eelgrass (Zostera marina) along a nutrient gradient in a Danish estuary. Mar Biol 87:211-218

Brown JR, Gowen RJ, McLusky DS (1987) The effect of salmon farming on the benthos of a Scottish sea loch. J exp mar Biol Ecol 109:39-51 
Burrell DC, Schubel JR (1977) Seagrass ecosystem oceanography. In: McRoy CP, Helfferich C (eds) Seagrass ecosystems. Marcel Dekker, New York, p 195-227

Cambridge ML, McComb AJ (1984) The loss of seagrasses in Cockburn Sound, Western Australia. I. The time course and magnitude of seagrass decline in relation to industrial development. Aquat Bot 20:229-243

Christiansen C, Christoffersen H, Dalsgaard J, Nornberg P (1981) Coastal and near-shore changes correlated with die-back in eel-grass (Zostera marina, L.). Sediment Geol $28: 163-173$

Correll DL, Wu TL (1982) Atrazine toxicity to submersed vascular plants in simulated estuarine microcosms. Aquat Bot 14:151-158

Cowper SW (1978) The drift algal community of seagrass beds in Redfish Bay, Texas. Contr mar Sci 21:125-132

Dahlback B, Gunnarsson LAH (1981) Sedimentation and sulfate reduction under a mussel culture. Mar Biol 63 $269-275$

Eckman JE (1987) The role of hydrodynamics in recruitment growth, and survival of Argopecten irradians (L.) and Anomia simplex (D'Orbigny) within eelgrass meadows. $\mathrm{J}$ exp mar Biol Ecol 106:165-191

Edgar GJ (1990) The influence of plant structure on the species richness, biomass and secondary production of macrofaunal assemblages associated with Western Australian seagrass beds. J exp mar Biol Ecol 137:215-240

Everett RA (1991) Intertidal distribution of infauna in a central California lagoon: the role of seasonal blooms of macroalgae. J exp mar Biol Ecol 150:223-247

Everett RA (1994) Macroalgae in marine soft-sediment communities: effects on benthic infaunal assemblages. $J$ exp mar Biol Ecol 175:253-274

Fonseca MS, Fisher JS (1986) A comparison of canopy friction and sediment movement between four species of seagrass with reference to their ecology and restoration. Mar Ecol Prog Ser 29:15-22

Fonseca MS, Zieman JC, Thayer GW, Fisher JS (1983) The role of current velocity in structuring eelgrass (Zostera marinal meadows. Estuar coast Shelf Sci 17:367-380

Frostick LE, McCave IN (1979) Seasonal shifts of sediment within an estuary mediated by algal growth. Estuar coast mar Sci 9:569-576

Geyer HE, Deegan LA, Finn JT, Ayvazian SG (1990) The effects of macroalgae on the abundance of eelgrass (Zostera marina) in the Waquoit Bay Estuary. Biol Bull 179:223 (abstract)

Giesen WBJT, van Katwijk MM, den Hartog C (1990) Eelgrass condition and turbidity in the Dutch Wadden Sea. Aquat Bot 37:71-85

Grebmeier JM, McRoy CP, Feder HM (1988) Pelagic-benthic coupling on the shelf of the northern Bering and Chukchi Seas. I. Food supply source and benthic biomass. Mar Ecol Prog Ser 48:57-67

Heck KL Jr, Able KW, Fahay MP, Roman CT (1989) Fishes and decapod crustaceans of Cape Cod eelgrass meadows: species composition and seasonal abundance patterns. Estuaries 12:59 65

Heck KL Jr, Orth RJ (1980) Seagrass habitats: the roles of habitat complexity, competition and predation in structuring associated fish and motile macroinvertebrate assemblages. In: Kennedy VS (ed) Estuarine perspectives. Academic Press, New York, p 449-464

Heck KL Jr, Thoman TA (1981) Experiments on predator-prey interactions in vegetated aquatic habitats. J exp mar Biol Ecol 53:125-134

Heck KL Jr, Thoman TA (1984) The nursery role of seagrass meadows in the upper and lower reaches of the Chesapeake Bay. Estuaries 7:70-92

Holme N, Mclntyre AD (eds) (1971) Methods for the study of marine benthos. IBP Handbook 16. Blackwell Scientific Publications, Oxford

Hull SC (1987) Macroalgal mats and species abundance: a field experiment. Estuar coast Shelf Sci 25:519-532

Hunter JV, Brown EE (1985) Crustacean and mollusk aquaculture in the United States. AVI Publishing Company, Inc, Westport, CT

Irlandi EA, Peterson CH (1991) Modification of animal habitat by large plants: mechanisms by which seagrasses influence clam growth. Oecologia 87:307-318

Jacobs RPWM, den Hartog C, Braster BF, Carriere FC (1981) Grazing of the seagrass Zostera noltii by birds at Terschelling (Dutch Wadden Sea). Aquat Bot 10:241-259

Joint IR (1978) Microbial production of an estuarine mudflat. Estuar coast mar Sci 7:185-195

Kaspar HF, Gillespie PA, Boyer IC, Mackenzie AL (1985) Effects of mussel aquaculture on the nitrogen cycle and benthic communities in Kenepuru Sound, Marlborough Sounds, New Zealand. Mar Biol 85:127-136

Kentula ME, McIntire CD (1986) The autecology and production dynamics of eelgrass (Zostera marina L.) in Netarts Bay, Oregon. Estuaries 9:188-199

Kikuchi T (1966) An ecological study on animal communities of the Zostera marina belt in Tomioka Bay, Amakusa, Kyushu. Publ Amakusa mar Biol Lab Kyushu Univ 1:1-106

Kikuchi $T$ (1980) Faunal relationships in temperate seagrass beds. In: Phillips RC, McRoy CP (eds) Handbook of seagrass biology: an ecosystem perspective. Garland STPM Press, New York, p 153-172

Lapointe BE, Niell FX, Fuentes JM (1981) Community structure, succession, and production of seaweeds associated with mussel-rafts in the Ria de Arosa, N. W. Spain. Mar Ecol Prog Ser 5:243-253

Larkum AWD, West RJ (1990) Long-term changes of seagrass meadows in Botany Bay, Australia. Aquat Bot 37:55-70

Lavery PS, McComb AJ (1991) Macroalgal-sediment nutrient interactions and their importance to macroalgal nutrition in a eutrophic estuary. Estuar coast Shelf Sci 32:281-295

Lubbers L, Boynton WR, Kemp WM (1990) Variations in structure of estuarine fish communities in relation to abundance of submersed vascular plants. Mar Ecol Prog Ser 65:1-14

Mattsson J, Linden O (1983) Benthic macrofauna succession under mussels, Mytilus edulis L. (Bivalvia), cultured on hanging long-lines. Sarsia 68:97-102

McRoy CP. Barsdle RJ, Nebort N (1972) Phosphorus cycling in an eelgrass ecosystem. Limnol Oceanogr 17:58-67

McRoy CP, McMillan C (1977) Production ecology and physiology of seagrasses. In: MCRoy CP. Helfferich C (eds) Seagrass ecosystems: a scientific perspective. Marcel Dekker, New York, p 53-87

Meinesz A, Laurent R (1978) Cartographie et état de la limite inférieure de l'herbier de Posidonia oceanica dans les Alpes-maritimes (France). Botanica mar 21:513-526

Menzel W (1991) Estuarine and marine bivalve mollusk culture. CRC Press, Inc, Boca Raton

Neilson B, Cronin L (1981) Estuaries and nutrients. Humana, Clifton, $\mathrm{NJ}$

Nicholls DJ, Tubbs CR, Haynes FN (1981) The effect of green algal mats on intertidal macrobenthic communities and their predators. Kieler Meeresforsch Sonderh 5:511-520

Odum HT (1963) Productivity measurements in Texas turtle grass and the effects of dredging on an intercoastal channel. Publ Inst mar Sci Univ Texas 9:48-58 
Odum HT, Copeland BJ, McMahan EA (1974) Coastal ecological systems of the United States, Vol III. The Conservation Foundation, Washington, DC

Olsen T, Burgess F (1967) Pollution and marine ecology Wiley-Interscience, New York

Orth RJ (1977) The importance of sediment stability in seagrass communities. In: Coull BC (ed) Ecology of marine benthos. University of South Carolina Press, Columbia p 281-300

Orth RJ, Heck KL (1980) Structural components of the eelgrass (Zostera marina) meadows in the lower Chesapeake Bay - fishes. Estuaries 3:278-288

Orth RJ, Heck KL, Van Montfrans J (1984) Faunal communities in seagrass beds: a review of the influence of plant structure and prey characteristics on predator-prey relationships. Estuaries 7:339-350

Orth RJ, Moore KA (1984) Distribution and abundance of submerged aquatic vegetation in Chesapeake Bay: an historical perspective. Estuaries 7:531-540

Ottman F, Sornin JM (1985) Observations on sediment accumulation as a result of mollusk culture systems in France. In: Chao NL, Kirby-Smith WW (eds) Proceedings of the International Symposium on Utilization of Coastal Ecosys. tems: Planning, Pollution, and Productivity, 21-27 Nov 1982, Rio Grande, Brazil. Editora da Furg, Rio Grande, RS, p 329-337

Patriquin DG (1975) 'Migration' of blowouts in seagrass bects at Barbados and Carriacou, West Indies, and its ecological and geological implications. Aquat Bot 1:163-189

Peres JM, Picard J (1975) Causes of decrease and disappearance of the seagrass Posidonia oceanica on the French Mediterranean coast. Aquat Biol 1:133-139

Petersen CGJ (1918) The sea bottom and its production of fish food. A survey of work done in connection with the valuation of the Danish waters from 1883-1917 Rep Dan Biol Stn 25:1-62

Peterson CH (1982) Clam predation by whelks (Busycon spp.): experimental tests of the importance of prey size, prey density, and seagrass cover. Mar Biol 66:159-170

Peterson CH (1986) Enhancement of Mercenaria mercenaria densities in seagrass beds: is pattern fixed during settlement season or altered by subsequent differential survival? Limnol Oceanogr 31:200-205

Pillay TVR (1992) Aquaculture and the environment Halsted Press, New York

Pollard DA (1984) A review of ecological studies on seagrass fish communities, with particular reference to recent studies in Australia. Aquat Bot 18:3-42

Posey MH (1988) Community changes associated with the spread of an introduced seagrass, Zostera japonica. Ecology 69:974-983

Pregnall AM. Rudy PP (1985) Contribution of green macroalgal mats (Enteromorpha spp.) to seasonal production in an estuary. Mar Ecol Prog Ser 24:167-176

Pregnall MM, Pregnall AM, Rumrill SS (1993) Recovery of an eelgrass Zostera marina community in areas disturbed by commercial oyster culture in the South Slough National Estuarine Research Reserve, Oregon. Abst 12th Biennial International Estuarme Research Federation Conference, November 14-18, 1993, Hilton Head Island, South Carolina. Estuarine Res. Federation, Port Republic, MD

Pulich WM, White WA (1991) Decline of submerged vegetation in the Galveston Bay System: chronology and relationships to physical processes. J coast Res 7:1125-1138

Reise K (1983) Sewage, green algal mats anchored by lugworms, and the effects on turbellaria and small polychaeta. Helgoländer Meeresunters 36:151-162
Ritz DA, Lewis ME, Shen M (1989) Response to organic enrichment of infaunal macrobenthic communities under salmonid seacages. Mar Biol 103:211-214

Rönnberg O, Adjers K, Ruokolahti C, Bondestam M (1992) Effects of fish farming on growth, epiphytes and nutrient content of Fucus vesiculosus $\mathrm{L}$. in the Aland archipelago, northern Baltic Sea. Aquat Bot 42:109-120

Shaw WN (1969) The past and present status of off-bottom oyster culture in North America. Trans Am Fish Soc 98: $755-761$

Shepherd SA, McComb A, Bulthuis D, Neverauskus V, West RJ (1989) Decline in some Australian seagrass beds. In: Larkum AWD, McComb AJ, Shepherd SA (eds) Seagrass ecosystems - an Australian perspective. Elsevier, Amsterdam, p 346-393

Short FT, Wolf J, Jones GE (1989) Sustaining eelgrass to manage a healthy estuary. Proceedings of the 6th Symposium on Coastal and Ocean Management, July 11-14, Charleston, SC. American Society of Civil Engineers, New York, p 3689-3706

Short FT, Jones GE, Burdick DM (1991) Seagrass decline: problems and solutions. Coastal Wetlands. Coastal Zone '91 Conference-ASCE, Long Beach, CA, July, 1991. American Society of Civil Engineers, New York, p 439-453

Sogard SM. Able KW (1991) A comparison of eelgrass, sea lettuce macroalgae, and marsh creeks as habitats for epibenthic fishes and decapods. Estuar coast Shelf Sci 33: 501-519

Sogard SM, Powell GVN, Holmquist JG (1987) Epibenthic fish communities on Florida Bay banks: relations with physical parameters and seagrass cover. Mar Ecol Prog Ser 40:25-39

Sokal RR, Rohlf FJ (1981) Biometry, 2nd edn. Freeman, San Francisco

Sornin JM, Feuillet M, Heral M, Deslou-Paoli JM (1982) Effet de biodepots de l'huitre Crassostrea gigas sur l'accumulation des matières organiques dans les parcs du bassin de Marennes-Oléron. J mollusc Stud (suppl) 12A.

Soulsby PG, Lowthion D, Houston M (1982) Effects of macroalgal mats on the ecology of intertidal mudflats. Mar Pollut Bull 13:162-166

Stoner AW (1980) The role of seagrass biomass in the organization of benthic macrofaunal assemblages. Bull mar Sci 30:537-551

Stoner AW, Lewis FG (1985) The influence of quantitative and qualitative aspects of habitat complexity in tropical seagrass meadows. J exp mar Biol Ecol 94:19-40

Summerson HC, Peterson CH (1984) The role of predation in organizing benthic communities of a temperate-zone seagrass bed. Mar Ecol Prog Ser 15:63-77

Taylor ARA (1954) Control of eelgrass in oyster culture areas. Fisheries Research Board of Canada, Atlantic Biological Station, St. Andrews, NB, General Series, No 23, Circular, February 1954

Tenore KR, and 14 coauthors (1982) Coastal upwelling in the Rias Bajas, NW Spain: contrasting the benthic regimes of the Rias de Arosa and Muros. J mar Res 40:701-772

Tenore KR, Corral J, Gonzalez N, Lopez-Jamar E (1985) Effects of intense mussel culture on food chain patterns and production in coastal Galicia, NW Spain. In: Chao NL, Kirby-Smith WW (eds) Proceedings of the International Symposium on Utilization of Coastal Ecosystems: Planning, Pollution, and Productivity, 21-27 Nov. 1982 Rio Grande, Brazil. Editora da Furg, Rio Grande, RS, p $321-328$

Thayer GW, Phillips RC (1977) Importance of eelgrass beds in Puget Sound. Mar Fish Rev 39:18-22 
Thayer GW, Kenworthy WJ, Fonseca MS (1984) The ecology of eelgrass meadows of the Atlantic coast: a community profile. US Fish Wildl Serv FWS/OBS-84/02

Thayer GW, Wolfe DA, Williams RB (1975) The impact of man on seagrass systems. Am Sci 63:288-296

Thomas MLH, Duffy JR (1968) Butoxyethanol ester of 2,4-D in the control of eelgrass (Zostera marina L.) and its effects on oysters (Crassostrea virginica Gmelin) and other benthos. Proc Northeast Weed Cont Conf 22:186-193

Tsutsumi H, Kikuchi T, Tanaka M, Higashi T, Imasaka K, Miyazaki M (1991) Benthic faunal succession in a cove organically polluted by fish farming. Mar Pollut Bull 23: $233-238$

Twilley RR, Kemp WM, Staver KW, Stevenson JC, Boynton WR (1985) Nutrient enrichment of estuarine submersed vascular plant communities. I. Algal growth and effects on production of plants and associated communities. Mar Ecol Prog Ser 23:179-191

Twilley R, Ejdung G, Romare P, Kemp WM (1986) A comparative study of decomposition, oxygen consumption and nutrient release for selected aquatic plants occurring in an estuarine environment. Oikos 47:190-198

van der Veer HW (1989) Eutrophication and mussel culture in the western Dutch Wadden Sea: impact on the benthic ecosystem - a hypothesis. Helgoländer Meeresunters 43: $517-527$

Waddell JE (1964) The effect of oyster culture on eelgrass (Zostera marina L.) growth. Master's thesis, Humboldt State University, Arcata, CA

Ward LG, Boynton WR, Kemp WM (1984) The influence of waves and seagrass communities on suspended particulates in an estuarine embayment. Mar Geol 59. $85-103$

This article was submitted to the editor
West RJ, Larkum AWD (1979) Seagrass primary productivity - a review. Proc Linn Soc NSW 106:213-223

Wilson KA, Heck KL Jr, Able KW (1987) Juvenile blue crab, Callinectes sapidus, survival: an evaluation of eelgrass, Zostera marina, as refuge. Fish Bull US 85:53-58

Wilson KA, Able KW, Heck KL Jr (1990) Predation rates on juvenile blue crabs in estuarine nursery habitats: evidence for the importance of macroalgae (Ulva lactuca). Mar Ecol Prog Ser 58:243-251

Winer BJ (1971) Statistical principles in experimental design, 2nd edn. McGraw-Hill Kogakusha, Tokyo

Ye LX, Ritz DA, Fenton GE, Lewis ME (1991) Tracing the influence on sediments of organic waste from a salmonid farm using stable isotope analysis. J exp mar Biol Ecol 145:161-174

Zieman JC (1974) Methods for the study of the growth and production of turtle grass, Thalassia testudinum Konig. Aquaculture 4:139-143

Zieman JC (1976) The ecological effects of physical damage from motor boats on turtle grass beds in southern Florida. Aquat Bot 2:127-139

Zieman JC (1982) The ecology of the seagrasses of south Florida: a community profile. FWS/OBS-82/25. US Fish and Wildilife Service, Office of Biological Services, Washington, DC

Zieman JC, Wetzal RG (1980) Productivity in seagrasses: methods and rates. In: Phillips RC, McRoy CP (eds) Handbook of seagrass biology: an ecosystem perspective. Garland STPM Press, New York, p 87-116

Zimmermann CF, Montgomery JR (1984) Effects of a decomposing drift algal mat on sediment pore water nutrient concentrations in a Florida seagrass bed. Mar Ecol Prog Ser 19:299-302

Manuscript first received: April 7, 1993

Revised version accepted: March 2, 1995 